\title{
Aspects of the resilience and settlement of refugee youth: a narrative study using body maps
}

\author{
Charity Davy', Lilian Vieira Magalhães ${ }^{\mathrm{b}}$, Angela Mandich ${ }^{\mathrm{b}}$, Sandra Maria Galheigo ${ }^{\mathrm{c}}$ \\ aChildren's Aid Society, Ontario, Canada \\ ${ }^{\mathrm{b}} \mathrm{S}$ chool of Occupational Therapy, Western University, Ontario, Canada \\ 'Faculdade de Medicina, Departamento de Fonoaudiologia, Fisioterapia e Terapia Ocupacional, Universidade de \\ São Paulo - USP, São Paulo, SP, Brasil
}

\begin{abstract}
Introduction: The primary concern of this study is to assist refugee youths in telling their transition story through art in order to understand facilitators and barriers to successful settlement in Ontario, Canada. Methods: This article briefly explains a new approach to visual methodologies, body mapping. Body maps are life-size human body images created through drawing, painting or other art-based techniques and can be developed with different purposes. In this project, these artifacts were used to elicit refugee youths' life stories in a more neutral and meaningful way than standard interviews. Results: The participants' migration journey is described in three phases: (1) pre-arrival; (2) arrival; and (3) settlement. Each participant is presented in a brief narrative story. The main themes presented in the data are discussed, namely faith, family, education, and future. Finally, the body maps and their application in health research addressing sites of (a) production, (b) image, and (c) audience are examined.
\end{abstract}

Keywords: Recognized Refugee, Narration, Resilience/Psychological, Art.

\section{Aspectos da resiliência e da integraçáo social de jovens refugiados: um estudo narrativo usando mapas corporais}

Resumo: Introdução: A principal preocupação deste estudo foi permitir que jovens refugiados contassem a sua história de integração em Ontário, Canadá, a fim de conhecer os facilitadores e as barreiras que concorreram para o seu sucesso. Métodos: O artigo explica brevemente os mapas corporais, que são imagens do corpo em tamanho real, criadas a partir de desenho, pintura e outras técnicas artesanais que são desenvolvidas com diversos propósitos. Neste projeto esses artefatos representam uma nova abordagem de pesquisa para obter as histórias de vida dos jovens de uma forma mais neutra e significativa do que as entrevistas padrão. Resultados: A trajetória de migração dos participantes é descrita em três fases: (1) pré-chegada; (2) chegada; e (3) integração. Cada fase é discutida em relação à história dos participantes. Cada participante é apresentado em uma breve história narrativa. Os principais temas apresentados nos resultados incluem fé, família, educação e futuro. Finalmente, a aplicação do modelo de análise dos mapas corporais em pesquisas de saúde que focalizam fatores como (a) a produção, (b) a imagem e (c) a audiência é examinada.

Palavras-chave: Refugiado Reconhecido, Narração, Resiliência Psicológica, Arte.

\section{Introduction}

The primary concern of this study was to assist refugee youths in telling their transition story through art in order to understand facilitators and barriers to successful settlement within Ontario, Canada.
Another dimension of this article briefly explains a new approach to visual methodologies, body mapping, which was used to elicit refugee youths' life stories in a more creative and meaningful way 
than standard interviews. The participants' migration journey is described in three phases: (1) pre-arrival; (2) arrival; and (3) settlement. Each phase will be discussed in relation to the participants' stories. Each participant will be introduced through a vignette and their body map. The main themes are presented in the data including, faith, family, friends, education, and future to name a few will be discussed. Finally, the body maps and their application in Rose's (2007) model addressing sites of (a) production, (b) image, and (c) audience are examined.

\section{Methods}

\subsection{Body mapping}

Body mapping has gained popularity over the past decade. Body mapping is a life-size representation of self, using art, slogans and symbolism to articulate one's life story. It is a creative process which allows the participant to reveal their history in a less confrontational way avoiding harmful recounts from the past through a life narrative (ART2BE, 2009). Body mapping originated in 2002 by Jane Solomon at the University of Cape Town, South Africa as a therapy for women with HIV/AIDS and has evolved into workshops for many other diseases, traumas, and living conditions (DEVINE, 2008; MacGREGOR, 2009; WIENAND, 2006). The use of body mapping is promising for research with refugee and immigrant populations where language/ literacy and cultural background may inhibit other approaches such as interviews (GASTALDO et al., 2012, 2013).

\subsection{Data collection}

The data collection process for this project consisted of two individual body mapping sessions and a third debrief and evaluation session. The first session included a demographic interview and focused on the youths' settlement experiences. This included body tracing and settlement journey activities as well as some homework to create a symbol, slogan and message to others. The homework piece allowed time for the participants to reflect on the messages they wanted to portray in their body map and was not meant to take up too much of their time. The second session focused on the life of a refugee youth after migration and included discussing personal symbols and slogans, marks on/under the skin, self-portraits, message to others, body scanning, and support structures. This session drew on the homework piece from session one. In the third session, a short evaluation of the study was filled out by each participant, the participants' body maps were returned to them laminated, and we discussed their experiences in the study.

The data collection was conducted in the community organization the participants were recruited from. In most cases, only the researcher and the participant were present, however in two separate cases participants asked if the organization's gatekeeper could also be present for the first session, which was promptly accepted. The body mapping and interview sessions one and two were audio recorded for further analysis.

Field notes and reflexive journaling were done after each interview as well as reviewing each transcript to reflect on issues, biases, and first impressions of the resulting data.

\section{Telling the stories of resilient refugee youth}

\subsection{Introducing the youth - Pre- arrival, arrival and settlement: who I am versus who I was}

\subsubsection{Pre-arrival/Arrival}

Before delving into the participants' settlement stories, it is important to understand the context from which refugee youths come (MAKHOUL; NAKKASH, 2009). In fact, the study by Brough et al. (2003, p. 202) on refugee mental health found that "[...] young people's experience of the present is very much mediated by their past."

Each participant had a unique life before coming to Canada, however the bitter sweet emotions of leaving home, family and friends and embarking on a new adventure in Canada links them. As Papadopoulos (2002 apud NAIDOO, 2008, p. 9) suggested, the "[...] loss of home is the only condition that all refugees share."

Although there were friends and family she had to leave, Claire was able to come with her entire immediate family and some extended family and she was younger making the move somewhat less stressful for her:

I wanted to know how everyone dressed and how like, what kind of food they eat and what does 
their school look like because my school was very different from now back then.

Figure 1 describes Claire and reveals her body map.

\subsubsection{Settlement}

Settlement is ongoing. It involves making new friends, adjusting to a new culture, language, city, food and school system to say the least. Khanlou (2008, p. 514) pointed out,

[...] while youth bring many resiliencies and positive hopes for their future in their new country of residence, they, along with their families, can face significant resettlement barriers within the first few years of their arrival.
Now that she is in Canada, Claire said she is the same but more confident to stand up for what is right. Michael, on the other hand, said his English is much better; he is smarter because he is older and has completed more school and he is very proud of this. When asked about what has changed since she has come to Canada, Rosette identified education:

[...] because like I know it's not free in Kenya but I just didn't like the education over there so like when I came to Canada I was so proud of myself like the way like I'm learning a lot of things. Yeah I think education is something really important for me like change. (Rosette).

Figure 2 describes Rosette and reveals her body map.

In her book, Resiliency: what we have learned, Benard (2004, p. 13) identified four categories of

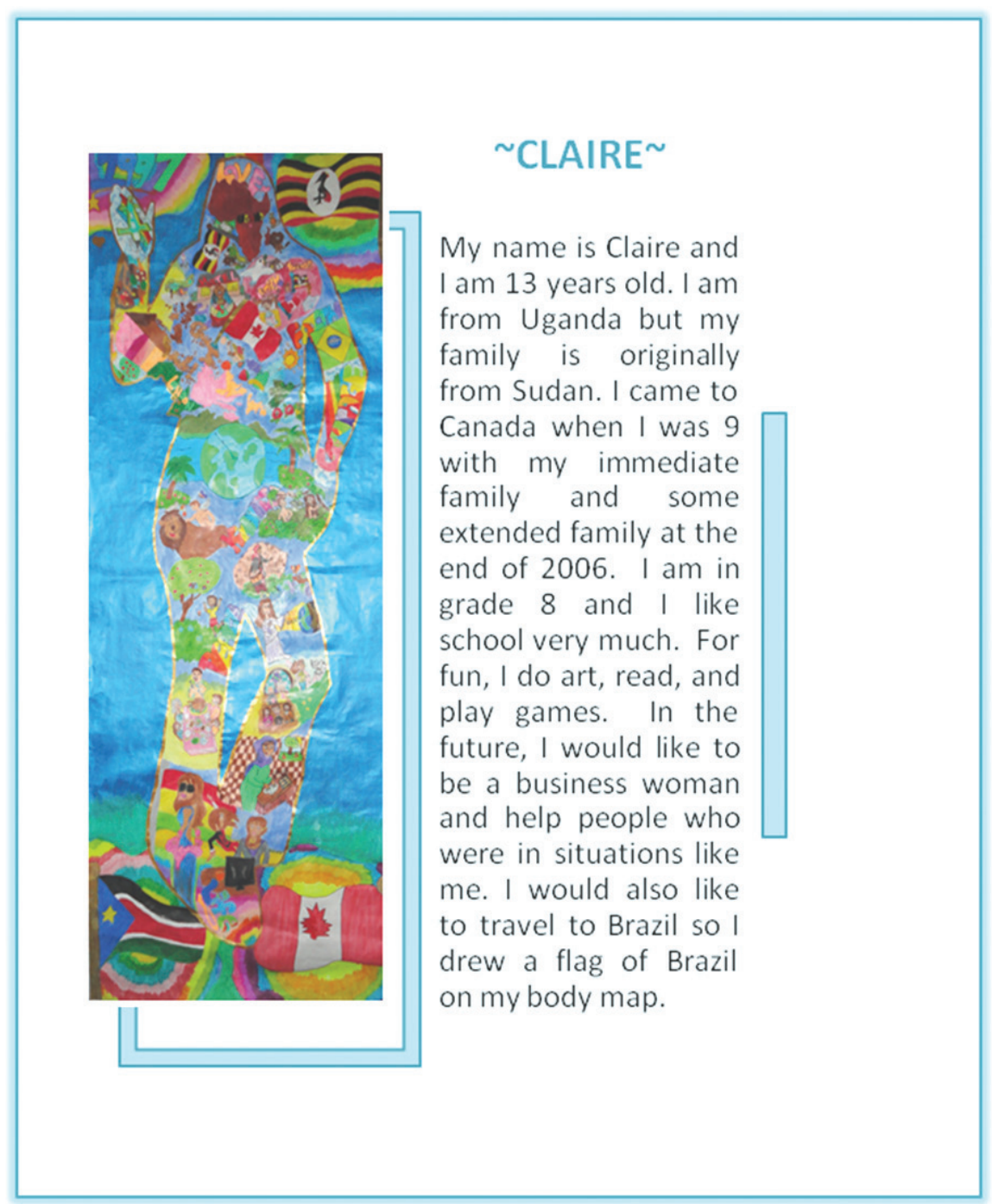

Figure 1. Claire's story and body map. 


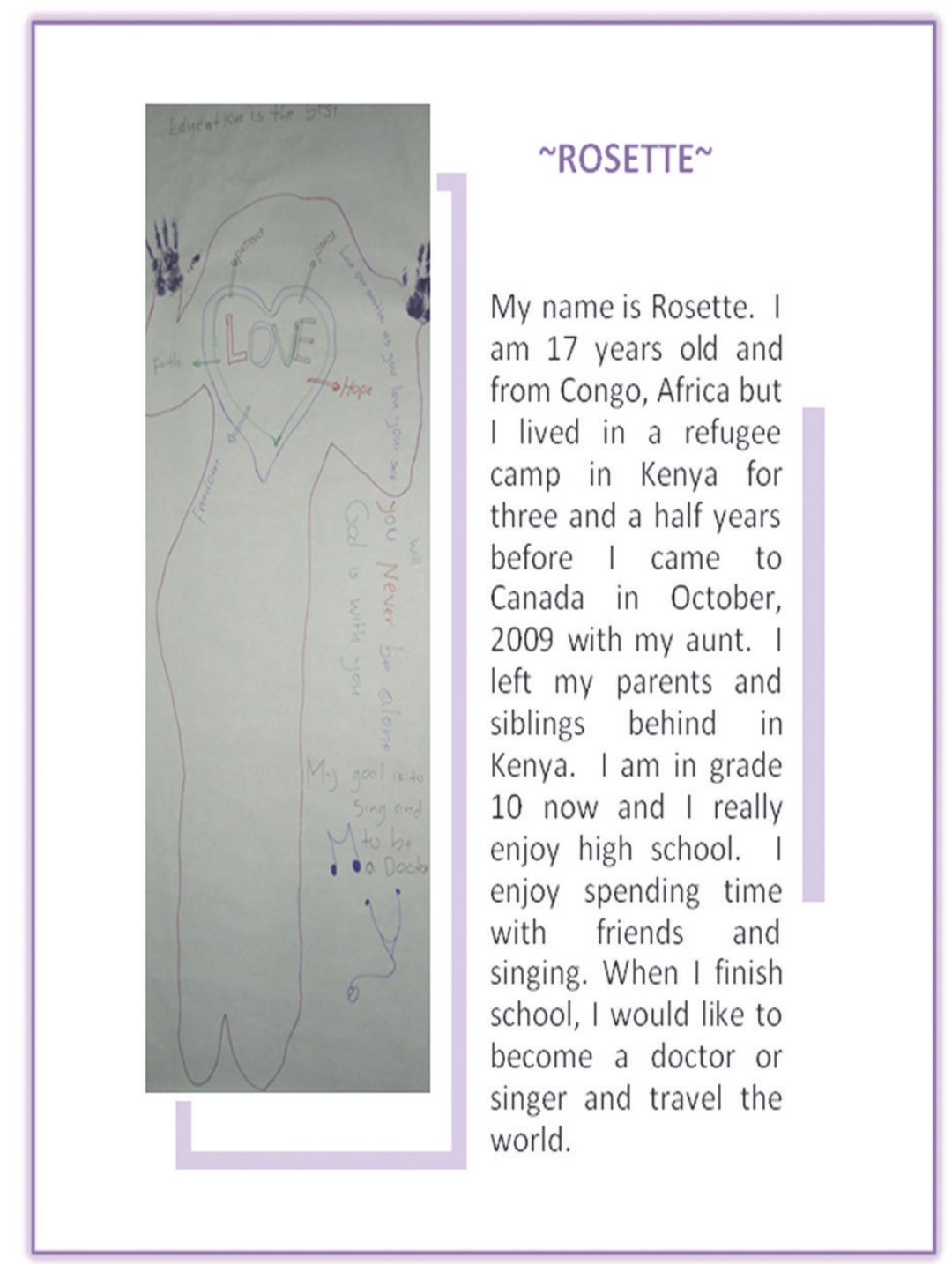

Figure 2. Rosette's story and body map.

personal strengths "or manifestations of resilience". These categories include (1) social competence, (2) problem solving, (3) autonomy, and (4) sense of purpose. Throughout their stories, each participant displayed qualities within these four domains, contributing to their resilience in settlement.

\subsubsection{Education}

By far, education was a clear and predominant theme within this study. All participants spoke of the opportunities it provided and said they truly enjoy and value school. For instance, Rosette wrote "Education is the best?" on her body map. Rosette also explained how important education is for finding a good job in the future.
The lack of or limitations to education in participants' place of origin due to cost, accessibility or war, may be a reason why education is so valued (NAIDOO, 2008). When parents bring their children to Canada, they likely have difficulty obtaining the kind of jobs that they may have been trained for thus the value of education in obtaining a well-paying job may be emphasized to them by their parents (WILKINSON, 2002). In Phan's (2003, p. 558) study on Vietnamese-Canadian youth, she found that success in school was "[...] seen as providing a way to pay back parents for the sacrifices they made in coming to Canada."

When speaking of opportunities present in Canada for refugee youth, Michael said, "There's no chance for them to not get an education." Figure 3 describes Michael and reveals his body map. 


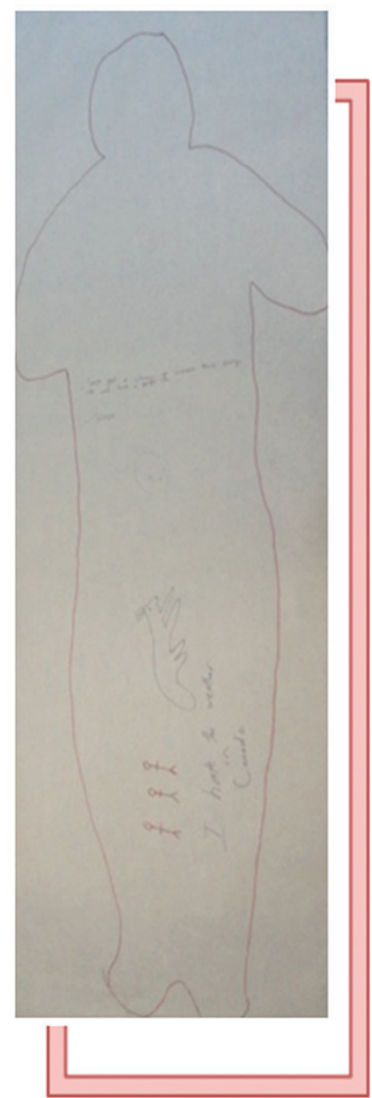

\section{MICHAEL}

My name is Michael and I am 18 years old. I left Palestine and lived with family in Ohio, US for a year before coming to Canada with some of my family in September, 2007. I just started my first year of college to become a chemical technician and I really enjoy school. For fun I go to the gym and play sports with my friends. I do not like the weather in Canada but I value the opportunities that are available to me here.

Figure 3. Michael's story and body map.

For Claire, something simple like a welcome card really helped to make her first day of school in Canada a great experience. Similarly, in Hek's (2005) study addressing the role of education in the settlement of refugee youth in the UK, she found that:

Where staff and pupils were encouraging towards them, this allowed them to identify as refugees and feel that their experiences and contributions were being valued; this helped them to gain a sense of belonging more quickly. (HEK, 2005, p. 165).

A warm gesture such as giving Claire a welcome card may have been a way to foster a sense of belonging which helped ease her transition regardless of potential barriers she would face in school such as language.

Education was clearly a significant facilitator in transitioning to Canada for all the participants. In fact, among the four categories of resilience, Benard (2004, p. 28) identified "[...] goal direction, achievement motivation, and education [...]" as characteristics revealing a sense of purpose. Cultural values placed on education may also play a part in facilitating settlement. Hek (2005, p. 159) found that "[...] schools are recognized and valued by most refugee communities."

The language difficulties faced by not being able to speak English when they first arrived evidently did not affect participants' zeal for education. The current English as a Second Language (ESL) classes offered through the Ontario education system is 
partly responsible for transitioning youth who speak a foreign language into the school system without imposing barriers such as costs to refugee families. In Lori Wilkinson's (2002, p. 173) study exploring the factors that influence academic success among refugee youth in Canada, she explained

[...] the school is one of the first sites where Canadian culture is introduced and learned, and it is also the site where much of their integration into Canadian society takes place.

With that said, language support is a large factor in facilitating transitions into the school and community for refugee youths (HEK, 2005).

\subsubsection{Language}

Language barriers were most prevalent in school because it was where Michael, Claire and Rosette spent most of their time when they arrived in Canada. However, all participants learned English primarily through school because none of them knew English well before coming to Canada. Participants' parents or guardians did not know English before coming either and have very limited use of the language. Michael acknowledged his English now is very good and he is proud of this. On the other hand, Rosette admitted that she still struggles with English,

\section{[...] when I came to Canada I had to learn like a new language... to come and start to learn a new language that was something that was really hard to me and it's still hard.}

Claire has been in Canada the longest. She said that she is scared of losing her first language, Anchori, even though she speaks it at home with her parents because she speaks English at school, where she spends the majority of her days. She feels like she knows English better than her first language now. Wilkinson (2002) confirmed that youths tend to master English faster than their parents because of their integration into the school system and its facilitation in acculturating youth to Canadian society.

Self-efficacy and mastery are among the properties of autonomy that contribute to resilience (BENARD, 2004). Those youth who feel they have mastered the English language enough to communicate effectively may have a stronger sense of autonomy and therefore, combined with other resilience factors, display a greater degree of resilience. As well, communication is a trait of social competence, which displays personal strength and has been consistently associated with success in education:
The ability to move back and forth between their primary culture and the dominant culture, or to accommodate the dominant culture without assimilating into it, means learning the "codes of power" while retaining their cultural and self-identities (BENARD, 2004, p. 15).

\subsubsection{Faith, hope and love}

Faith was a predominant theme amongst the female participants. It became clear early on in the first session that both Claire and Rosette had Christian values. For instance, the last question of the demographic interview asks about participants' health status, specifically if they have any health concerns. Rosette responded, "No, I'm good. God loves me!" as she laughed. Similarly, the majority of Claire's first session focused on drawing a dove in her right hand. This symbolized God releasing a dove to watch over her as she came to Canada. She said, "He's with me wherever I go." Claire also drew a girl exploring the outdoors with a dove flying above her. She explained, "It's leading the girl to the right place." Also, in Rosette's body map, she wrote "[...] you will never be alone, God is with you [...]", and she said, "God is with you everywhere you go no matter what." When I asked Rosette where her power comes from, she replied "God". The belief that God is with Claire and Rosette always, to protect and lead them is clearly a supportive factor in their lives.

In their body maps, Claire and Rosette drew many symbols and words to represent faith. For example, Claire drew her family in the pews at church to illustrate that her family goes to church. Rosette goes to church also but she did not choose to represent this in her body map. In addition, Claire drew a dove (to represent God), a church and a Bible in her heart to embody the significance faith has in her life as a support. She also drew Adam and Eve in the garden and Adam with a lion and other animals signifying the life they had before sin and asserted, "[...] when I look at them, I think of the bad things they did and how they you know, they disobeyed God and why we need to I guess listen." Claire drew an angel and when explaining her drawing spoke of her afterlife, "[...] when I think, I pass away I want to be an angel, give peace to the world." Faith was therefore a huge influence on the message Claire and Rosette wanted to portray in their body map.

Faith has been demonstrated as a protective factor for refugee youth as making sense of the trauma youth have experienced (GOODMAN, 2004), providing a community of support (SOMMERS, 2001), and being a mediating factor for successful settlement 
(HALCÓN et al. 2004; STAUFFER, 2008). In addition, faith, spirituality, a sense of meaning, and hope are all attributes that foster a sense of purpose and are "[...] associated with healthy development throughout the lifespan." (BENARD, 2004, p. 32). These personal strengths contribute to making meaning "[...] whether by attributing meaning to that outside one's control or by creating one's own meaning." (BENARD, 2004, p. 32). Similarly, these attributes are holistic in nature positively affecting the mind, body, and spirit, contributing to risk reduction. The "making of meaning" (BENARD, 2004 , p. 34) that arise from these elements are transformative allowing one to not only overcome the pain and suffering experienced in the past but also to live a gratifying life.

It is interesting to note that Michael did not mention faith at all. This may be influenced by the religious history in the participants' countries of origin. For instance, Michael is from Palestine, which is riddled with religious strife. The IsraeliPalestinian conflict is widespread with no hopes of being settled in the near future. This religious and political turmoil may have influenced Michael's faith potentially even deterring him altogether. As Claire mentioned, the church was instrumental in helping Claire and her family come to Canada and to settle in Ontario, which has clearly influenced her goals for the future and facilitated her transition to Canada. This positive experience with the church may have been a significant factor in developing and sustaining her strong belief system.

Finally, Claire and Rosette both wrote virtues on their body maps such as courage, patience, hope, faith, peace, freedom and love to represent characteristics that have helped them transition and given them strength throughout the settlement process.

Similarly, Michael wrote hope on his body map. He said, "Here people get a chance to learn new things and to improve their English, basically everything so there's always hope for all of these things to improve." Whether their hope is in God or the opportunities available to them here in Canada, Michael, Claire, and Rosette clearly have hope and think it is an important part of successful settlement.

\subsubsection{Family and friends}

It is no surprise that family was a major theme throughout the data collected. The type of support families give generally extends beyond mental support to address more practical everyday needs such as providing shelter, food, clothing and transportation to some degree. For instance, all the participants rely on the city bus for transportation to some degree, however, when Claire's uncle was available, he would give her rides. Similarly, Rosette was able to get rides from friends. Although Michael has his driving permit, he joked and said he would much rather use a donkey as a mode of transportation as he reflected on the lifestyle back home and spending time with his family in the garden.

For each participant, family may mean something different. Rosette left her immediate family in Kenya and came to Canada with her aunt. However, since her aunt is the only relative Rosette has in Canada, the value of friendship may be more pronounced for Rosette. In contrast, Claire came with her immediate family, some uncles, aunts, cousins and her grandma. Claire identified her family as a support that gives her courage. She enjoys being with her family and is really close to them. In our conversation, Claire admitted that she doesn't know if her support is reciprocated equally to theirs.

Since isolation, boredom and lack of supervision can lead to risk taking behaviours, having supportive family to turn to is a protective factor for refugee youth (ROSSITER; ROSSITER, 2009).

In her body map, Claire drew a family sitting at a table filled with a variety of food and explained: "This is the family having Christmas, my favorite holiday. It brings the whole family together."

Michael came to Canada with his parents and six of 10 siblings so he also has a large family to rely on; however, he only spoke about his parents as being a support:

\section{My parents did [support me] in the situation when I first came because I didn't know anything, was something new to me. The weather was different, the plane was different, but then after that I just, I became, I just had to learn. Slowly, slowly things became normal. (Michael).}

Michael chose family as a symbol to represent his migration journey. Michael's parents navigated the system for his family when they first came to Canada securing housing, finances and schooling: "It was hard when I first came but right now it's okay, like I can just do everything basically by myself." Michael and his parents are close.

As in his home country, friends and family have helped Michael on his settlement journey. Michael was in seventh grade when he left home, but he still connects with his friends from home through Facebook.

Social competence displayed from eliciting responsiveness from family and friends is a 
manifestation of resilience and is "[...] one of the five ingredients of emotional intelligence." (BENARD, 2004, p. 14). Building relationships and communicating effectively, as Claire, Rosette, and Michael displayed through continued relationships with family and friends cultivated personal strength and therefore, resilience.

\subsubsection{Time}

Michael was the only participant who discussed the concept of time as a facilitating factor in settlement. Michael said: "Once you're here for like 2 years or something you just forget about everything. It becomes easier." Although only one participant revealed time as a facilitating factor to successful settlement, it is important to note its relevance to mastery and an internal locus of control that foster autonomy (BENARD, 2004). This author explained that both mastery and an internal locus of control are associated with "personal power" (BENARD, 2004, p. 22) and contribute to one feeling as if they can handle the situation, in this case, Michael's past and his settlement experience. Similarly, Wilkinson (2002, p. 189) reported that "[...] as time in a new country increases, so does the integration of newcomers [...]", which can influence educational success because newcomers become familiar to the new language, school system, and life in their new country in general.

\subsubsection{Plans for the future}

For young people from a refugee background, the desire for better futures is more poignant as they seek to establish secure futures not only in a new social, cultural and geographical space but in a new adult space as well (BROUGH et al., 2003).

Likewise, planning is a key factor in problem solving leading to the development of resilience factors (BENARD, 2004). Planning requires a sense of control and "hope for the future" (BENARD, 2004, p. 17) facilitating positive outcomes in later life. Both Claire and Rosette had various long term goals for the future. Claire said she wants to be a business woman to help people:

I was thinking of working at a church because there's people who helped my mom at church and help us came here and made our lives more easier and I think I want to be like, more like those people...yeah. (Claire).

Claire wants to travel to Brazil to see the monkeys that fit in your hand and because "[...] there's like some places in Brazil, I think there's like people who don't ... like... have things that like I have or something." This thought was not elaborated on further but it may have alluded to helping people. Regardless, this comment proves that she is aware that some people in the world are not as privileged as she is. Claire also wants to travel across Canada. However, when I asked her if she would like to visit Uganda, she said she has no plans of going back because of war.

Rosette wants to travel across the world as well but her motivation in doing so is to help people. She wants to be a singer or doctor. Her experience in a hospital in Kenya in which she saw many people suffering and some even dying due to a doctor shortage demonstrates personal reasons for wanting to become a doctor.

Michael's goal is to finish college to become a chemical lab technologist and then he would like to work. This may reflect the age gap between him and the other participants since he is 18 and at a different stage in his life that requires more direct planning in order to become more financially stable and secure through work.

Although the qualitative nature of this study prevents generalizations, clear gender differences may exist in the types of goals participants would like to pursue for the future. Sociological structures such as gender roles and cultural histories influence goal setting among youth (BAIRD; BURGE; REYNOLDS, 2008; FOSTER, 2005). Michael had one goal, to get through school so he could work, which may have been influenced by historical and cultural patriarchal perspectives in which men typically are the household providers and are socialized to work (BAIRD; BURGE; REYNOLDS, 2008). Claire and Rosette had many goals. Primarily, their goals stemmed from a desire to help others. As well, the female participants' goals included multiple activities, both personal and career oriented. This may reflect a matriarchal perspective that emphasizes the role of women as caregivers (STAEHELI, 2003; FOSTER, 2005). This historical perspective asserts,

[...] as women have been seen as the protectors of personal relations in the household, it makes some sense that protecting the relations in the community would also be a feminine task." (STAEHELI, 2003, p. 820).

Accordingly, women are also said to be more conversational (FOSTER, 2005), reflective, in touch with their feelings, and future oriented making it easier for them to recall their hopes and goals for the future. 
Likewise, the sense of empathy, caring, altruism and compassion that guides Claire and Rosette's goals for the future are traits of social competence demonstrating personal strengths and therefore resilience (BENARD, 2004). Known as the "fundamental people skill" (BENARD, 2004, p. 15), empathy

[...] not only helps facilitate relationship development, it also helps form the basis of morality, forgiveness, and compassion and caring for others (GOLEMAN, 1995 apud BENARD, 2004, p. 15).

As a result, altruism is said to be "empathy in action" (BENARD, 2004, p. 15) and is found in many resilient adults who learned to love others and help to alleviate their pain despite their own. Similarly, many physiological and psychological benefits are documented from experiences of compassion, "[...] the desire and will to care for and to help alleviate another's suffering." (BENARD, 2004, p. 16). Claire and Rosette's goals evidently display a sense of social competence whereas Michael's goals demonstrate a sense of autonomy and self-sufficiency, which are also important factors influencing resilience.

\section{Methodological considerations on Body Mapping: exploring the production, image, and audience}

Every person has a different way of knowing, understanding and being in the world and therefore, no one person will see and interpret an image the same as another so it is important to justify interpretations in research (HARTMAN et al., 2011). Gillian Rose (2007), an expert in visual methodologies and author of Visual methodologies: an introduction to the interpretation of visual materials advocated for a critical approach to visual methodology that emphasizes reflexivity as the basis for interpretation. Rose (2007, p. xiv) also provided guidelines of justifying interpretations of images produced through visual methodologies and suggested that "interpreting images is just that, interpretation". She suggested that the meaning of an image is made at three sites, the site(s) of: (1) production of the image - how it was made; (2) the image itself - components of the image; and (3) the audience - the relationship between the image and the intended message (13). Here, we examine the production, image and audience associated with sharing a narrative through body mapping.

\subsection{Production}

The production of participants' body maps varied greatly. For instance, it was clear in the first session that Claire had a plan of what she wanted to do with her body map and that it would require more time to facilitate her vision. On the other hand, Rosette and Michael were much more verbal about their stories and felt more comfortable explaining them rather than drawing. Simple things like a candid conversation or providing more time to work helped facilitate the production of the body maps.

\subsection{Self-efficacy in art}

Throughout the body mapping process, each participant was self-conscious with their artistic skill at some point. Michael did not like the body mapping portion of the sessions very much. It was clear that he preferred to tell me his experience rather than draw it. Phrases such as "I can't draw" and "I don't know how to draw well" were frequently expressed by Michael. Michael's lack of self-efficacy with drawing prevented him from drawing various symbols to portray his story. In one instance, Michael wanted to draw a donkey to represent his experience back home but he did not think it looked good so he decided it would be a rabbit instead. Michael's ability to joke about his skill facilitated his storytelling.

Rosette had a similar experience with comments such as "[...] but I'm not good at drawing, I'm scared like I'm going to make some mistake though [...]" and "[...] but I'm not perfect to draw though I don't know, maybe you can tell me what I'm going to do." However, at some points she would ask me to help her instead of avoiding drawing a symbol altogether. In instances like these, we had lengthy discussions to discuss what the symbol might look like.

Even Claire, who seemed to be most comfortable with the artwork out of all the participants, expressed insecurities when drawing, "Can you do it for me because I can't draw... I'm bad at drawing hands." She wanted me to draw her hands but we decided we would trace them and she would draw inside of them.

No one drew a self-portrait of their face, Rosette and Michael because they did not feel they could do a good enough job and Claire because she wanted to put other symbols there.

\subsection{Image}

Claire had plans to put up the complete laminated body map on her wall. We talked a bit about the 
experience of body mapping and Claire really enjoyed it even though it was a lot of work.

Although Rosette did not talk about what she had planned for her completed body map, she was very excited to receive it and seemed to like the outcome of her work. Michael's body map was sent to him by a third part, so we did not get to observe his reaction to his finished body map.

\subsection{Audience: the message to other refugee youth}

The participants were given an opportunity to provide both a slogan and message to other refugee youth coming to Canada. Michael's slogan was "[...] people get a chance to improve their daily life and have a better life." He also said that successful settlement "[...] helps make you a better person." Claire, however, chose to talk about courage and wrote, "If you have courage, it's Claire [...]" by her head "... because courage comes from your mind." Similarly, Rosette made a visual slogan by drawing a heart and putting strong words around it.

Although none of the participants discussed how they felt about communicating their stories with others, each participant had a message to give to other refugee youths. We cannot speculate if they were afraid to be judged or excited to tell their stories. However, from the experience, they all seemed to easily open up during the second session and relatively enjoyed the process, which may suggest that they enjoyed telling their story and reflecting on their experiences.

\section{Implications for future studies and final Remarks}

We suggest researchers embrace visual methodologies including body mapping. The use of visual methodologies has many benefits for working with youths. Visual methodologies provide engaging forms of knowledge creation, and collaboration that helps to break down power imbalances. In particular, body mapping is a great tool for exploring youths' experiences in a manner that helps participants make meaning of their experiences and reminds them of their strengths.

Finally, the relationship between resilience and health status should be investigated in more detail. Clearly the relationship between mental health and resilience seems to be strong; therefore further longitudinal investigation may reveal with greater certainty the factors that influence successful settlement and resilience among youths (KUMPFER, 1999).

In this project, the overall goal was to facilitate changes in attitudes, policies, and services to foster resilience in refugee youth and identify their needs as a priority within the Canadian context. This shift in perspective should enhance the integration of the most at-risk refugee youths into Canadian society successfully but should also provide insights for further investigation in other social contexts.

\section{Acknowledgments}

The warmest and most heartfelt thank you to those youths who volunteered their time and their settlement stories to contribute to this thesis and to the gatekeepers along the way for their support, encouragement and organizational contribution but should also provide insights for further investigation in other social contexts.

\section{References}

ART2BE. Art for Positive Living and Social Change. Kenyan, 2009. Available from: <http://www. art2bebodymaps.com//index.php?option=com frontpage\&Itemid=1>. Access in: 2 may 2009.

BAIRD, C. L.; BURGE, S. W.; REYNOLDS, J. R. Absurdly ambitious? Teenagers' expectations for the future and the realities of social structure. Sociology Compass, Oxford, v. 2, n. 3, p. 944-962, 2008. http:// dx.doi.org/10.1111/j.1751-9020.2008.00110.x

BENARD, B. Resiliency: what we have learned. San Francisco: WestEd, 2004.

BROUGH, M. et al. Young refugees talk about well-being: a qualitative analysis of refugee youth mental health from three states. Australian Journal of Social Issues, Strawberry Hills, v. 38, n. 2, p. 193-208, 2003.

DEVINE, C. The moon, the stars, and a scar: body mapping stories of women living with HIV/AIDS. Border Crossings, Winnipeg, v. 27, n. 1, p. 58-65, 2008. Available from: <http://dignitasinternational.org/media-coverage/ the-moon-the-stars-and-a-scar-border-crossings/ $>$. Access in: 2 may 2009.

FOSTER, E. Desiring dialectical discourse: a feminist ponders the transition to motherhood. Women's Studies in Communication, Philadelphia, v. 28, n. 1, p. 57-83, 2005.

GASTALDO, D. et al. Mapas corporais narrados: um método para documentar saúde, resiliência, adoecimento e sofrimento. In: FRAGA, A. B.; CARVALHO, Y. M.; GOMES, I. M. (Org.). As práticas corporais no campo da saúde. São Paulo: Hucitec, 2013. p. 83-100.

GASTALDO, D. et al. Body-Map storytelling as research: methodological considerations for telling the stories of undocumented workers through body mapping. Toronto: [s.n.], 2012. Available from: <www.migrationhealth.ca/ 
undocumented-workers-ontario/body-mapping >. Access in: 20 may 2009.

GOODMAN, J. H. Coping with trauma and hardship among unaccompanied refugee youths from Sudan. Qualitative Health Research, Newbury Park, v. 14, n. 9, p. 1177-1196, 2004. PMid:15448294. http://dx.doi. org/10.1177/1049732304265923

HALCÓN, L. et al. Trauma and coping in Somali and Oromo refugee youth. Journal of Adolescent Health, New York, v. 35, n. 1, p. 17-25, 2004. PMid:15193570. http:// dx.doi.org/10.1016/j.jadohealth.2003.08.005

HARTMAN, L. R. et al. How do we 'see'occupations? An examination of visual research methodologies in the study of human occupation. Journal of Occupational Science, Melbourne, v. 18, n. 4, p. 292-305, 2011. http:// dx.doi.org/10.1080/14427591.2011.610776

HEK, R. The role of education in the settlement of young refugees in the UK: the experiences of young refugees. Practice, New York, v. 17, n. 3, p. 157-169, 2005.

KHANLOU, N. Young and new to Canada: promoting the mental wellbeing of immigrant and refugee female youth. International Journal of Mental Health and Addiction, New York, v. 6, n. 4, p. 514-516, 2008. http://dx.doi. org/10.1007/s11469-007-9071-y

KUMPFER, K. Factors and processes contributing to resilience: the resilience framework. In: GLANTZ, M.; JOHNSON, J. (Org.). Resilience and development: positive life adaptations. New York: Kluwer, 1999. p. 269-277.

MACGREGOR, N. H. Mapping the body: tracing the personal and the political dimensions of HIV/AIDs in Khayelitsha, South Africa. Anthropology \& Medicine, Abingdon, v. 16, n. 1, p. 85-95, 2009. http://dx.doi. org/10.1080/13648470802426326

MAKHOUL, J.; NAKKASH, R. Understanding youth: using qualitative methods to verify quantitative community indicators. Health Promotion Practice, Washington, v. 10, n. 1, p. 128-135, 2009. PMid:17971480. http://dx.doi. org/10.1177/1524839907301423
NAIDOO, L. Supporting African refugees in greater Western Sydney: a critical ethnography of after-school homework tutoring centres. Educational Research for Policy and Practice, Dordrecht, v. 7, n. 3, p. 139-150, 2008. http://dx.doi.org/10.1007/s10671-008-9046-1

PHAN, T. Life in school: narratives of resiliency among Vietnamese-Canadian youths. Adolescence, Roslyn Heights, v. 38, n. 151, p. 555-556, 2003.

ROSE, G. Visual methodologies: an introduction to the interpretation of visual materials. 2nd ed. London: Sage Publications, 2007.

ROSSITER, M. J.; ROSSITER, K. R. Diamonds in the rough: bridging gaps in supports for at-risk immigrant and refugee youth. Journal of International Migration and Integration, Dordrecht, v. 10, n. 4, p. 409-429, 2009. http://dx.doi.org/10.1007/s12134-009-0110-3

SOMMERS, M. Young, male and Pentecostal: urban refugees in Dar es Salaam, Tanzania. Journal of Refugee Studies, Oxford, v. 14, n. 4, p. 347-367, 2001. http:// dx.doi.org/10.1093/jrs/14.4.347

STAEHELI, L. A. Women and the Work of Community. Environment and Planning, London, v. 35, n. 5, p. 815-831, 2003. http://dx.doi.org/10.1068/a35134

STAUFFER, S. Trauma and disorganized attachment in refugee children: integrating theories and exploring treatment options. Refugee Survey Quarterly, Oxford, v. 27, n. 4, p. 150-163, 2008. http://dx.doi.org/10.1093/ rsq/hdn057

WIENAND, A. An evaluation of body mapping as a potential HIVIAIDS educational tool. Cape Town: University of Cape Town, 2006. p. 1-32. (CSSR Working Paper, n. 169). Available from: <http://www.cssr.uct.ac.za/sites/cssr.uct. ac.za/files/pubs/wp169.pdf>. Access in: 2 may 2009.

WILKINSON, L. Factors influencing the academic success of refugee youth in Canada. Journal of Youth Studies, Abingdon, v. 5, n. 2, p. 173-221, 2002. http:// dx.doi.org/10.1080/13676260220134430

\section{Author's Contributions}

All the authors are responsible for the manuscript conception, writing and revisions. 